\title{
Gender equity in the Argentine tax system: an estimation of tax burdens by household type ${ }^{1}$
}

\author{
Darío Rossignolo
}

\begin{abstract}
The purpose of this paper is to introduce the gender dimension into the analysis of tax incidence in Argentina. To that end, the impact of direct and indirect taxes on income and distribution by gender is calculated to establish the progressivity of taxes and the effects on gender equity when household classifications are analysed. The findings show that while the tax system is moderately progressive and the heaviest burden falls on households with male breadwinners, differences emerge when the impact of indirect and direct taxes is considered separately. The indirect tax system is heavily regressive and female-breadwinner households bear the largest burden, since they are concentrated in the lower income brackets. Households with children bear the highest direct tax burden, particularly male-breadwinner and dual-earner households.
\end{abstract}

\section{Keywords}

Fiscal policy, taxation, gender, households, income, gender equality, Argentina

\section{JEL classification}

H2, I3, D3

\section{Author}

Darío Rossignolo is an associate professor at the University of Buenos Aires and a researcher and consultant for different international organizations. Email: darossignolo@ gmail.com. 


\section{Introduction}

One of the main requirements of tax policy design is to know how the total tax take is distributed across different income levels. A tax system satisfies the "vertical equity" criterion when sectors with a greater tax payment capacity actually pay a greater proportion of tax than others, while "horizontal equity" exists when sectors with the same level of well-being, or ability to pay, do in fact pay the same proportion of tax (Lambert, 1993).

Tax systems have major implications for class and gender equity, since effective tax collection is a necessary, albeit not sufficient, condition for the amelioration of gender-based poverty and inequality. Low aggregate tax collection has implications for gender equity because it prevents the establishment of programmes to counteract the market distribution of income, in which women are generally disadvantaged. Not only do they provide the bulk of unpaid care work, but such paid work as they do is more likely than men's to take place in the informal sector, and if they do work in the formal sector they tend to be employed in smaller enterprises and to earn less than men (Grown and Valodia, 2010).

Gender analysis studies the impact of taxes and tax policies on intra-household welfare. The aim of this paper is to analyse the impact of the tax system on gender equity in Argentina. The analysis will be performed using the National Household Expenditure Survey (ENGHo) conducted by Argentina's National Institute of Statistics and Censuses (INDEC) from March 2012 to February 2013. Consequently, the tax codes employed will be those applicable in 2012.

The present study is structured as follows. Section II presents theoretical considerations regarding the incidence analyses and the gender evaluation of tax systems, together with a brief description of the Argentine context in terms of the gender dimension and a review of the results of previous studies on this issue. Section III introduces the overall tax situation, showing the composition of tax revenues and its evolution. Section IV presents the conceptual framework for the analysis of the intra-household impact of taxes, the legal framework for the tax system in Argentina and the methodology used to calculate economic and gender incidence. Section $V$ shows the results of the incidence analysis of income and gender inequality. Section VI summarizes and concludes.

\section{General theoretical considerations and empirical background}

The tax incidence analysis performed in this paper is consistent with the partial equilibrium literature and is known as the accounting approach, the aim being to analyse who pays what taxes to the State. It is worth noting that the concept of "incidence" used in this paper refers to the amount of taxes paid by each household. Although that information is sometimes obtained directly from sample surveys, inference may be necessary at other times, as taxes may not be directly observed in surveys and may have to be worked out indirectly. In accordance with Bourguignon and Da Silva (2003), indirect methods involve applying official income tax schedules or imputing payment of indirect taxes by observing spending.

Accounting approaches, however, ignore possible behavioural responses by agents that may modify the amounts they actually pay or receive; an accounting approach would not detect tax evasion prompted by an increase in income tax rates, for example. These approaches are limited to first-round effects and do not consider second-round effects attributable to behavioural responses, which behavioural approaches do try to take into account. 
In the case of goods taxes, the calculation of tax incidence should ideally entail estimation of the compensating variation, indicating by how much real income declines as a result of the tax. In accordance with Sahn and Younger (2003), the method used approximates that calculation from the compensating variation. When there is a marginal change in the price of a good, this variation is simply the change in the consumption budget that is necessary to keep the consumption basket constant. In other words, the demand response to the tax may be ignored as a first approximation (Sahn and Younger, 2003).

In order to develop methodologies consistent with the theoretical background, the burden generated by taxes on goods and services is assumed in this study to be fully passed on to consumers, so that what is considered are the statutory rates on each of the expenditure items surveyed. The tax burden represented by direct taxes, conversely, is shifted backwards to the income source by reducing earners' disposable income.

The key variable for analysing taxes paid by each quintile and household category is the tax burden, i.e. the ratio of taxes to pre-tax per capita income. A tax will be progressive if the ratios increase with rising welfare levels; conversely, it will be regressive if the burden decreases with per capita income (through statistical significance).

\section{Analysing gender bias in tax systems}

In her analysis of the existence of gender biases in tax systems, particularly in the case of personal income tax, Stotsky (1996) points out that this sort of discrimination can be explicit, implicit or both. While explicit gender bias is a feature of many tax systems, being expressed in the language used in the tax code or tax regulations, implicit gender bias is more difficult to identify, since it arises from the different implications that the provisions of tax law and regulations have for men and women, which in turn derive from value judgments regarding desirable social and economic behaviour. Although individual filing systems are usually more gender-equitable than joint ones, they still often contain explicit and implicit gender biases.

According to Grown (2010), one manifestation of explicit gender bias is the allocation of deductions, exemptions and other tax preferences on the basis of sex. For instance, deductions may be different depending on whether the income earner is in the formal sector or self-employed. Since men are more likely to be employees and less likely to form a single-parent household than woman, they are more likely to be in households with a lower personal income tax burden. These provisions of the law constitute implicit biases against women, who account for the bulk of self-employed single-parent households. Additionally, it is important to point out that tax codes provide exemptions for interest or dividend payments. Considering that men are more likely to own stocks and equities than women, this constitutes another form of implicit gender bias.

When it comes to indirect taxes, a factor not considered in the discussion of personal income tax has to be taken into account: gender differences in consumption patterns. It might be, for instance, that the incidence of indirect taxes is in fact lower for female-headed households than for others because women tend to purchase and consume less of the types of goods subject to the highest indirect taxes (e.g. alcohol and tobacco).

Stotsky (1996) argues that a system of indirect taxation in which taxes are higher for alcohol than for many other goods is biased against men. She takes the view that an unbiased system requires that goods and services which are disproportionately consumed by males should not be taxed at a different rate from goods which are disproportionately consumed by females. Likewise, higher rates of value added tax (VAT) on medical care are implicitly biased against women, because these goods are disproportionately consumed by them. 
This argument stems from Stotsky's view that bias comes from treating women and men differently, when they should be treated the same (i.e. violating the principle of horizontal equity). But this implies that consuming alcohol and tobacco and consuming medical care are equally socially valuable forms of behaviour, and equally a matter of personal, utility-yielding choice. ${ }^{2}$

However, it is widely regarded as justifiable to tax merit goods and basic necessities at a lower rate than demerit goods and luxuries. Consequently, to have higher tax rates for goods disproportionately consumed by men (and lower tax rates for goods disproportionately consumed by women) does not violate the principle of equity between women and men if the goods consumed disproportionately by men are "demerit" and/or luxury goods and the goods disproportionately consumed by women are "merit" goods and/or basic necessities. The relevant principle here is that of vertical equity, which permits people in differing situations to be treated in appropriately different ways.

In view of the likely impact of the two taxes on the behaviour of women and men and the possibility of men shifting the burden of alcohol taxes on to other household members, this needs further consideration. Typically, consumers of alcohol do not reduce their alcohol purchases if the price rises. There is a danger that men will respond to a rise in the price of alcohol by cutting back on spending on goods that benefit other household members. Likewise, if there is a rise in VAT on daily necessities (e.g. soap, salt, kerosene) that women have responsibility for buying, there is evidence to suggest that the resulting rise in their prices tends to lead women to cut back on their own consumption and spend more of their time producing home-made substitutes.

There is considerable evidence that women's bargaining power within households tends to be weaker than men's (Doss, 2011). This suggests that a plausible hypothesis is that men have a greater capacity to transfer the burden of indirect consumption taxes (such as excise duties and VAT) on to other household members than do women. If this is the case, indirect consumption taxes will have a substantially unequal impact on women and men, with a greater impact on women than on men.

\section{Analysis of gender bias in the Argentine personal income tax code ${ }^{3}$}

Argentina has adopted the principle of individual filing: each taxpayer must file a personal tax return (where applicable) ${ }^{4}$ irrespective of civil status and pay taxes on his or her taxable income. Income deriving from personal activities, personal property and property acquired with the proceeds of the spouse's profession, employment, etc., should be allocated as appropriate to each spouse.

Under an individual tax regime, however, gender bias can be found in three different cases. First, there is the allocation of non-employment income. Employment income is allocated to the employee, but the allocation of other source income, such as real estate income, is not so clear. Different countries' tax regimes allocate these types of income in different ways: they may be allotted to the spouse with higher income; they may be distributed equally between the spouses; the spouses may be allowed to decide on the allocation; or the income may be allocated to the spouse who owns the real estate generating it.

\footnotetext{
2 It would be helpful for updated research to be produced on these issues to confirm the persistence of these consumption patterns across different societies.

3 This section is based on Rodríguez Enríquez, Gherardi and Rossignolo (2010).

4 As will be discussed later, personal income tax may be paid through tax returns, by being withheld from wages and salaries or under the simplified monotributo regime.
} 
Second, tax exemptions may be applied differently depending on the tax regime followed. Tax provisions generally admit tax exemptions on different grounds, including the need to provide for a dependent spouse and young children. Under an individual tax return regime, the distribution of these exemptions between the spouses may not be fair; e.g. certain exemptions may be admitted for husbands with a dependent wife, but not for wives with a dependent husband. Third, some countries apply different rates to men and women, and tax rates are higher for married women than for married men.

Of these three possible types of discrimination, the third does not apply in Argentina, as men and women are subject to the same tax rates; the first two, however, should be assessed in relation to the application of personal income tax. This is because, in the case of married couples, a number of exemptions allocate certain common types of source income to the husband, examples being income from community property, which is wholly allocated to the husband in almost all cases; income from joint property has to be filed in the husband's tax returns.

It is generally accepted that the current regime is not quite the individual taxation regime that it appears to be, but rather a hybrid, as it contains cases where the spouses are subject to a kind of joint taxation. However, it is worth noting that this bias does not imply an economic penalty for women.

\section{The gender equity context in Argentina}

The average population growth rate in Argentina is $1.1 \%$ a year. Family organization has been changing very slowly. Population growth has been slowing, and is projected to be below a cumulative $1 \%$ a year by 2040 . This is because of a reduction in the average family size as couples have fewer children, an increase in one-parent households, the relative decline of large extended families and the corresponding pre-eminence of the nuclear family. The nuclear household predominates in Argentina (57.5\% of total households) and the great majority (85.8\%) of such households are headed by a man. In contrast, women head $58.7 \%$ of one-person households and $75.5 \%$ of one-parent households. ${ }^{5}$

The unemployment rate was 7.6\% in 2013 (6.6\% for men and 9.0\% for women). Among adults aged 15 to 64 , unemployment was higher for women (6.9\%) than for men (4.5\%) as of 2013, while among the young (aged 15-24) the female unemployment rate was $24 \%$ and the male rate $18 \%$.

The proportion of informal workers was still in excess of $39 \%$ of the economically active population in 2013. A higher proportion of women (42.4\%) than of men (36.8\%) were in informal employment. ${ }^{6}$ The figures show that women enter and leave the labour force more frequently than men, which means that their participation is more discontinuous and they are more likely to be in part-time and seasonal jobs, while a larger proportion of men are in full-time positions.

In Argentina, as shown in table 1, the male labour force is larger and more stable than the female one. The situation is not homogeneous across different income levels, since labour force participation is substantially lower among lower-income women than among those earning more, implying that the gender gap progressively widens down the income quintiles (Rodríguez Enríquez, Gherardi and Rossignolo, 2010). The presence of small children in the home continues to be one of the main factors precluding women's entry into the labour market, and becomes more of an obstacle the lower a household's income level.

\footnotetext{
5 SEDLAC (CEDLAS and the World Bank).

6 SEDLAC (CEDLAS and the World Bank). The definition of informality employed here deems all wage workers in small firms, the non-professional self-employed and zero-income workers to be informal.
} 


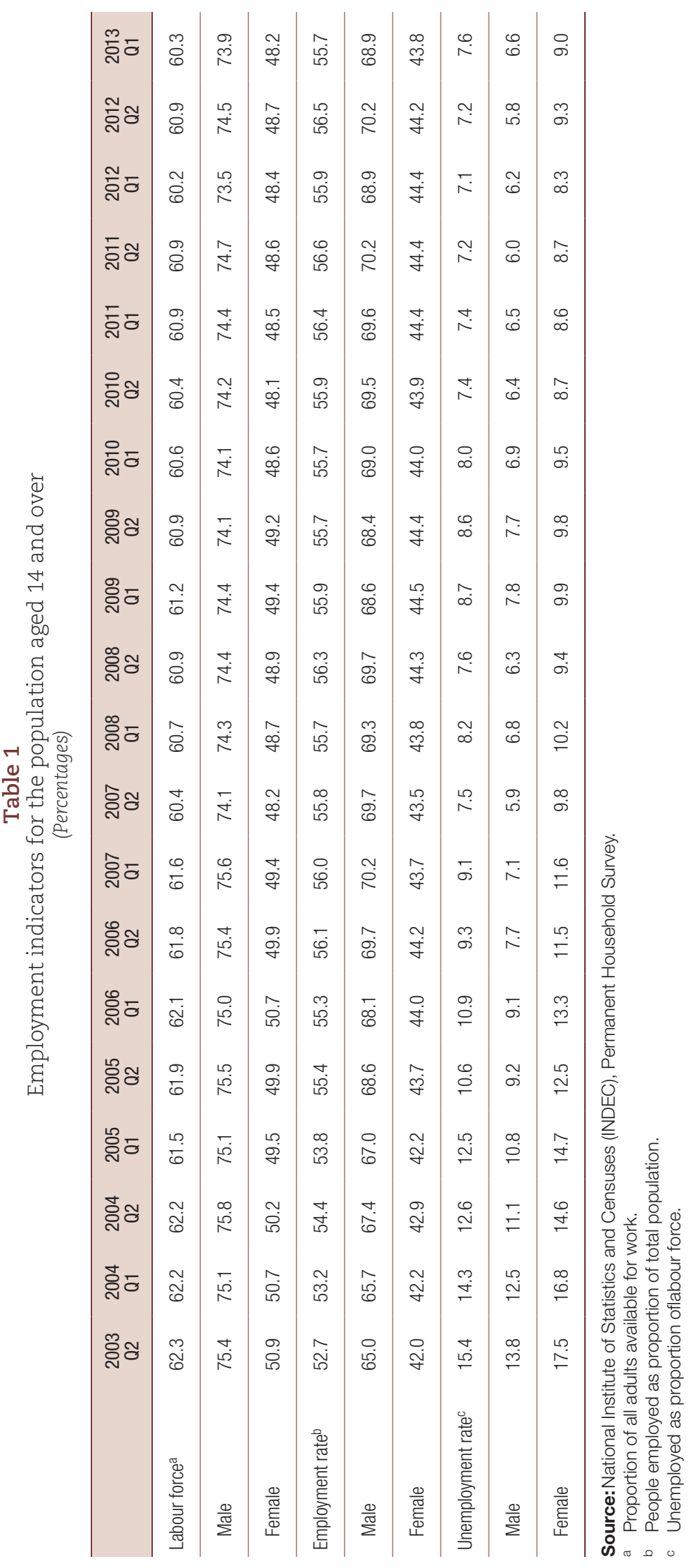


Secondly, individual income is lower for women than for men. Although the official statistics show that the gap is narrowing, female earnings are still less than about $60 \%$ of men's, rising to $70 \%$ when income from all sources is considered. This demonstrates that men's earnings are more likely to derive from formal employment than women's (see figure 1). Women's lower incomes, i.e. the continuing income gap between women and men, can be explained by higher unemployment, unstable employment and the higher proportion of women in less formal jobs.

Figure 1

Women's income as a proportion of men's

(Percentages)

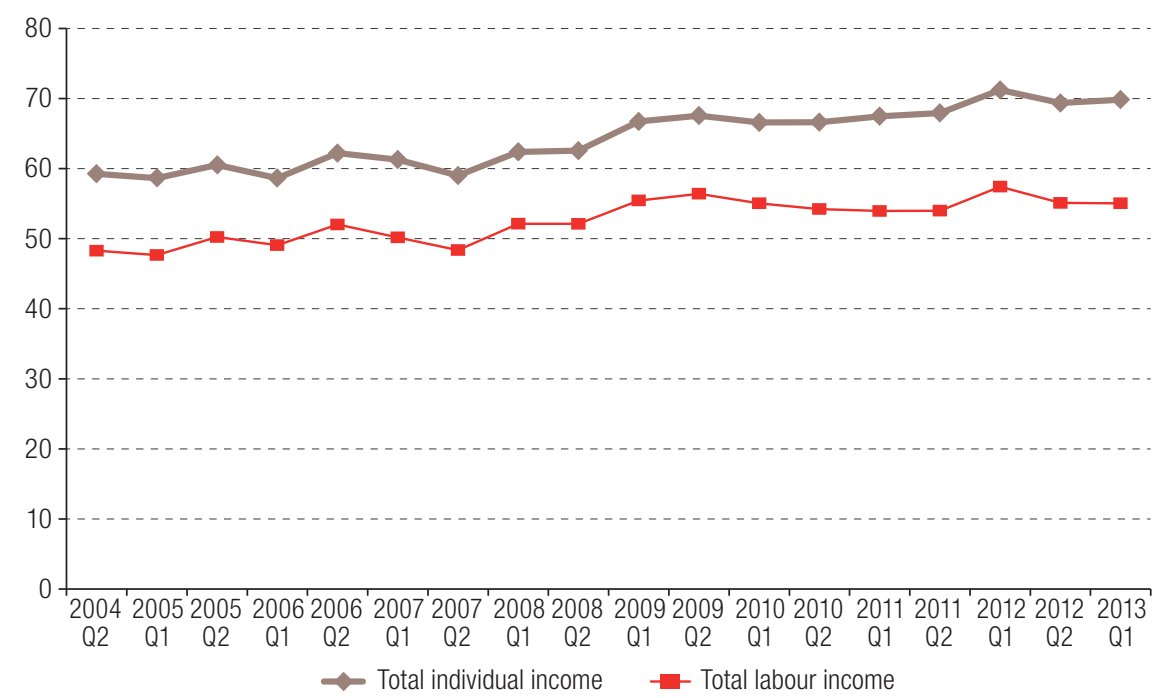

Source: Prepared by the author on the basis of National Institute of Statistics and Censuses (INDEC), Permanent Household Survey.

Third, women predominately work in informal employment, which excludes them from the income tax net (Grown, 2010). Women's employment profile, involving discontinuous employment, lower earnings and a predominance of informal employment, mean they tend to lack access to benefits provided to formal employees through the tax system.

Women in Argentina not only hold fewer of the available jobs than men, but are still more likely to be in poor-quality jobs. ${ }^{7}$ Women are overrepresented in (i) part-time work, (ii) informal wage work, (iii) low-skilled jobs, (iv) temporary or time-limited work and (v) domestic work (Rodríguez Enríquez, Gherardi and Rossignolo, 2010).

In addition to having fewer available employment options than men, women continue to be overrepresented in lower-quality and less-skilled jobs. While $36.8 \%$ of male wage earners were in informal jobs in 2013 , the share was $42.4 \%$ for women. As for less-skilled jobs, segregation into specific occupations persists. While $44.1 \%$ of all active women work in social services, men are still predominant in construction and manufacturing. Furthermore, domestic service continues to be the largest source of female employment, accounting for $17.2 \%$ of active women and $22.7 \%$ of female wage earners. This continues to be a highly insecure and poorly paid job option.

The reasons given above explain the earnings gap referred to earlier. This gap is the combined result of the different types of discrimination outlined (lower participation, higher unemployment and underemployment, horizontal and vertical segregation) and the fact that women work fewer hours than men because of a number of restrictions, such as the presence of small children in the home.

7 In 2013, 33\% of men's work time was spent on unpaid work, while this took up 73\% of women's total working time (CEPALSTAT). 
The fact that women find it more difficult than men to participate fully in the labour market translates into greater income vulnerability. This is particularly important because women are overrepresented in the types of households that struggle most, such as single-parent households. Male-headed households of these types have almost 30\% more income than female-headed ones. All this translates in turn into differences in the tax-paying capacity of men and women, which impacts the tax structure in various ways.

There are also differences in consumption expenditure patterns across household types. Compared to men, women tend to spend a higher proportion of the income under their control on goods such as food, education and health care that enhance the well-being and capabilities of children; these patterns affect tax incidence.

\section{The findings of previous studies on Argentina}

Although some tax incidence analysis has been done in Argentina, very few studies have included a gender perspective. Gasparini (1998) performs an analysis of the distributional impact of the tax system in 1996, taking per capita income and per capita consumption expenditures as welfare indicators. Taxes are highly regressive when considered in relation to the former but moderately progressive when per capita consumption is considered. Gómez Sabaini, Santiere and Rossignolo (2002) analyse the impact of taxes on income distribution for 1997, the welfare measure taken being per capita income adjusted for underreporting. The incidence is regressive in this case, with VAT and indirect taxes leading this impact.

Gómez Sabaini, Harriague and Rossignolo (2013) consider the incidence of taxes for 2008, again on the basis of per capita income. They find them to be proportional or slightly progressive, with the main impact coming from export taxes and an increased role for income tax and payroll taxes, as measured by the Gini coefficient. However, differences are greater at the extremes (decile 10 versus decile 1), prompting the conclusion that the system remains regressive in that respect.

Rodríguez Enríquez, Gherardi and Rossignolo (2010) is the only example of an incidence analysis with a gender perspective. The analysis performed covered only indirect taxes at a national level, using per capita consumption expenditure as a welfare indicator, and was based on information for 2005. The tax burden was found to be highest for dual-earner households, male-breadwinner households and male-majority households. The distribution impact of indirect taxes was the combined result of VAT that was somewhat regressive, excise duties that were strongly regressive and a fuel tax that was strongly progressive. Indeed, for all household types, the first expenditure quintile was found to bear a larger VAT burden than the other quintiles.

\section{The overall tax structure in Argentina}

The Argentine public sector has a long history of structural imbalances (Gómez Sabaini and Rossignolo, 2009). Taking the last 10 years, the average public sector surplus declined from 3.2\% of GDP between 2004 and 2008 to $0.5 \%$ of GDP between 2009 and 2013, while the average primary balance declined from a surplus of $1.6 \%$ of GDP to a deficit of $1.2 \%$ of GDP. Although the tax burden rose steadily (as will be shown in the next section), public expenditure increased by even more, with the result that deficits became the rule at both levels of aggregation from 2012 onward. 
The tax burden in Argentina has grown exceptionally strongly over the last decade, reaching $31.2 \%$ of GDP in 2013, ${ }^{8}$ as taxes that were used sporadically in previous periods, such as duties on exports (withholdings) and banking transactions, have been made permanent, while other provisions with an impact on corporate income tax and personal income tax have been applied, so that financial statements and thresholds are no longer adjusted for inflation, for example. This is illustrated in figure 2, where the banking transactions tax is included together with property taxes in accordance with the International Monetary Fund (IMF) classification of taxes. Export taxes have become substantial, but their share of the total has declined due to the fall in international commodity prices.

Figure 2

Gross national and provincial tax burden, 2004-2013

(Percentages of gross domestic product)

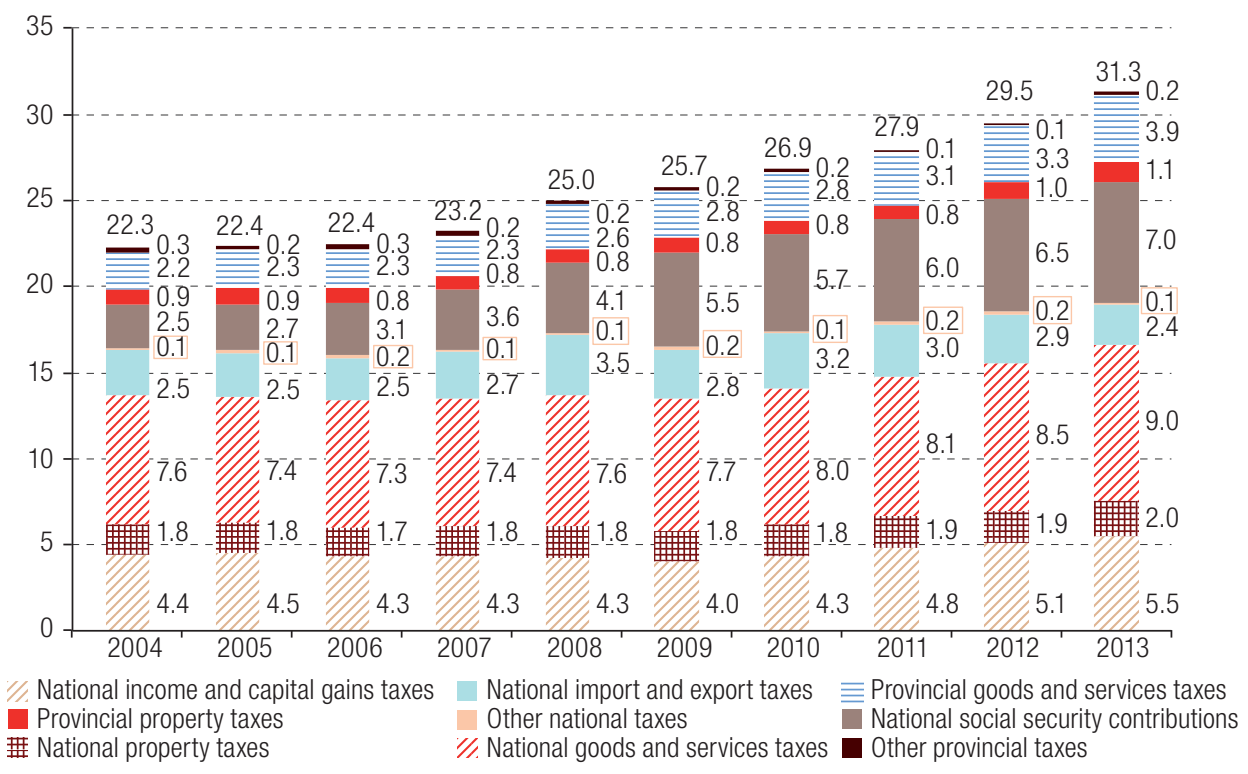

Source: Ministry of Treasury and Public Finance.

The bulk of this tax burden consists of indirect taxes; however, the relative shares of different kinds of taxes have changed slightly. As can be seen in figure 3, taking revenue from national and provincial goods and services taxes together, almost $42 \%$ of tax revenue came from indirect taxes in 2013. Among them, general consumption taxes (principally VAT) continued to account for by far the largest share (around 60\%). When excise taxes alone are considered, fuel taxes accounted for the greatest share (around 60\%), with tobacco ranking second (24\%), although its share has been declining.

Revenues from social security contributions increased their share in 2008 to become the largest source of direct tax revenues. This was due to the abolition of the capitalization system set up in the 1990s, all of whose resources were taken over by the government to create a pay-as-you-go system.

In short, the increase in the tax burden has been largely accounted for by a number of what may be considered extraordinary or emergency taxes. In addition, the emphasis during this decade has been on tax administration measures. It is therefore clear that the Argentine tax reforms were intended to avoid fiscal imbalances rather than improve gender equity.

8 Gross tax burden, excluding reimbursements. Revenue from health insurance contributions has been added to tax revenues in the case of formal sector workers, for whom they are compulsory. These figures are substantially lower, however, than those available before the official GDP recalculation (taking 1993 as the base year). The new figures reduced official nominal GDP (taking 2004 as the base year) and the tax burden by some 5\% of GDP. 
Figure 3

Composition of national and provincial taxes, 2004-2013

(Percentages)

\section{A. Indirect taxes}

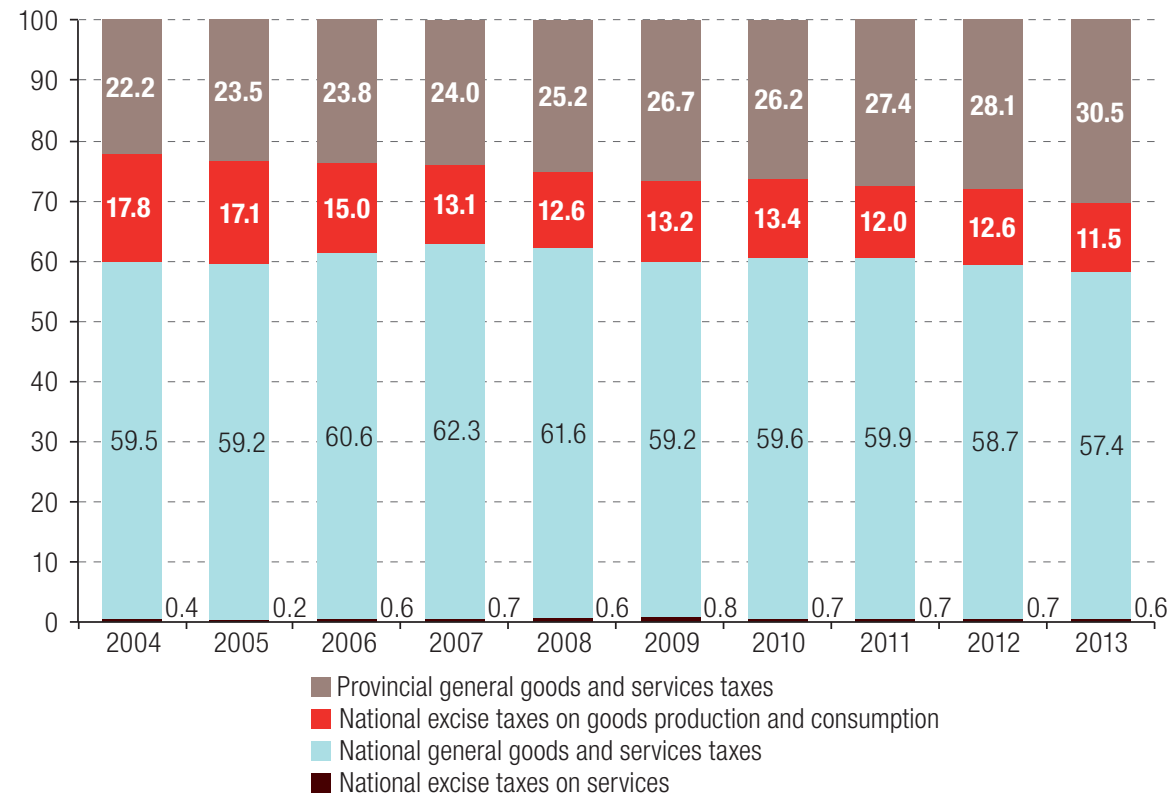

\section{B. Direct taxes}

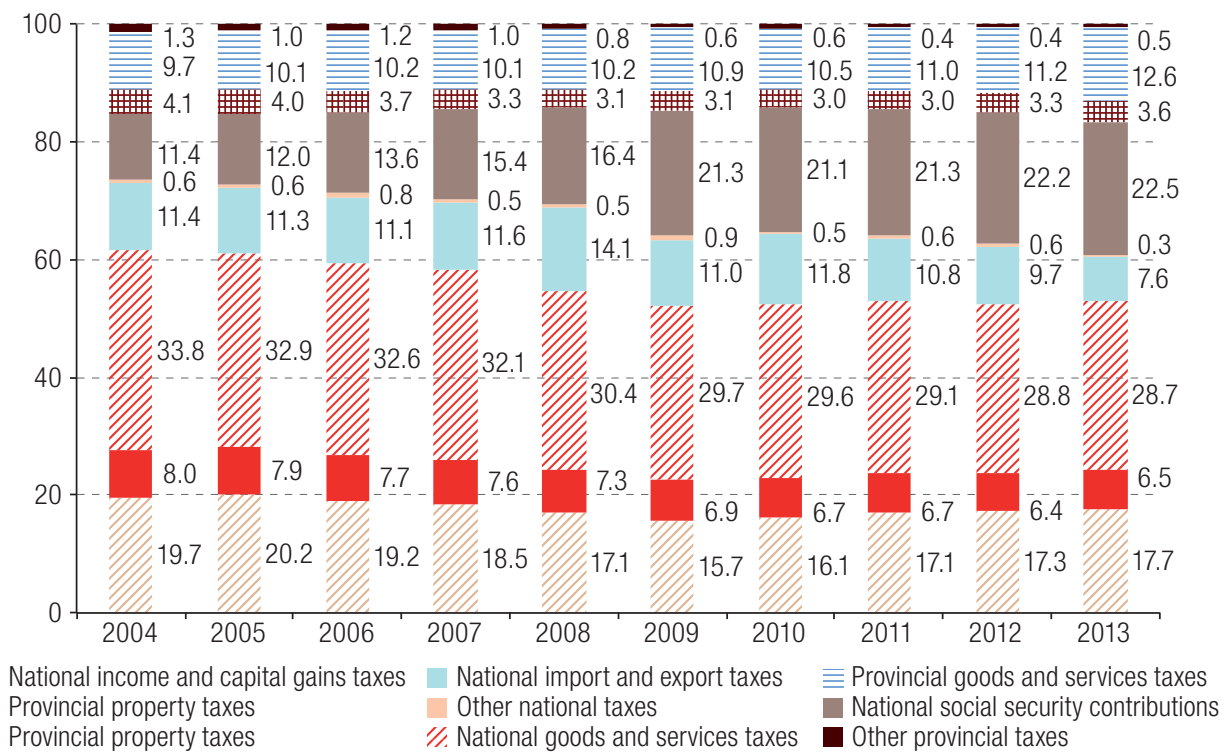

Source: Ministry of Treasury and Public Finance. 


\section{Tax incidence analysis: methodological considerations}

The present paper not only updates previous research on the subject by using information from the ENGHo for 2012/2013, but also includes indirect taxes levied at the provincial level. Additionally, it includes calculations that take per capita income as a welfare indicator in addition to estimating the incidence of direct taxes.

The main source of information for this report was the ENGHo, a large-scale survey that obtains detailed answers from about 20,960 households across the country drawn from a population of some 36.1 million. ${ }^{9}$ The units analysed by the survey are individual households and its main study variables are household expenditure and income, but it also includes information on demographic, occupational and educational variables and on housing characteristics, transfers in kind received and household goods. ${ }^{10}$

\section{Distribution of the welfare indicator}

Traditional incidence studies rank the analysis unit by current income. However, if someone's consumption shifts between periods, their welfare will be better related to permanent income. This issue can be solved if people are ranked by permanent income or its best proxy, consumption.

From a gender point of view, the impact of taxes on poorer households is of greatest interest, given that women tend more than men to be grouped into lower-income households. Income will therefore be taken as the welfare indicator, despite the enormous difficulty of obtaining accurate values for this variable from household surveys, which may cast doubt on the reliability of the data reported. Income thus includes the earnings of wage workers, employers, self-employed workers, recipients of capital income, social security beneficiaries, pensioners and beneficiaries of public transfers.

While the aim is to capture pre-tax income distribution, the income reported in household surveys includes public transfers, so that they provide a post-tax measure (adjusted for differences between regional prices). To calculate pre-tax income, public transfers (monetary and non-monetary) should be excluded. These include pensions, and in cases where a pension is someone's only income, subtracting this item would leave the household with zero income, making it look as though it were paying taxes and purchasing items despite having no income, and overstating the impact of taxes. To avoid these drawbacks, public pensions have been kept in the definition of disposable income and treated as part of pre-tax income.

This applies to monetary and non-monetary transfers as well. Dropping these transfers from income would imply that individuals did not use income from this source for consumption and therefore pay taxes. However, the household survey does not distinguish what type of transfer a household is receiving, so these transfers have been kept in the income definition and in the welfare indicator. This definition has been used in the calculation of quintiles and for the whole of the incidence analysis.

\footnotetext{
9 The ENGHo uses a representative sample of $86.8 \%$ of the population, as it excludes only towns with less than 5,000 inhabitants. Reach the whole population of the country would mean taking account of the portion of the urban population that is not included in the sample as well as rural areas, which are explicitly excluded because of the high operating costs that incorporating them would entail. No official statement has been made about the reliability of the survey.

10 See INDEC (2013) for the definitions of income and expenditure used in the survey.
} 


\section{Gender analysis through a household typology}

In order to carry out the gender analysis, the quintiles were calculated as described and divided into different categories by household composition within each quintile. The classification presented here is related to the occupational characteristics of household members and is aimed at identifying income and consumption expenditure patterns for a specific household composition in terms of gender. Occupational status is associated with the receipt of personal income by adult members of each household. Households are classified by the number of employed and unemployed men and women in them (Grown and Valodia, 2010), with inactive members being considered unemployed. The classifications are:

- Male-breadwinner households: at least one employed male in the household and no employed females, with and without children.

- $\quad$ Female-breadwinner households: at least one employed female in the household and no employed males, with and without children.

- Dual-earner households: at least one employed male and one employed female, with and without children.

- $\quad$ Non-employed households: no-one employed, with and without children.

The first two categories are of single-earner households, the third of dual-earner households and the last of households where no-one is employed, with each of these categories being divided between households that do and do not include children (under 18). Table 2 breaks down the different types of household by the number of people therein.

Income distribution is shown in table 3 for comparative purposes. The incomes reported there are not taken straight from the household survey but have been reconstructed to arrive at pre-tax amounts, since reported income for formal workers is after taxes.

What is analysed is the household income distribution, which is divided into household per capita income quintiles. The first quintile accounts for $4.1 \%$ of total income and the top quintile for approximately 53.5\%. Average monthly income per household is around US\$ 681 in current dollars at the 2012 exchange rate. Male-breadwinner households contain $46.3 \%$ of all individuals in the first per capita income quintile, female-breadwinner households $16.4 \%$ and dual-earner households $25.5 \%$.

Table 3 shows the percentage structure of household per capita income by quintile of individuals, grouped by aggregated income sources before taxes. The information in this table must be combined with that in the previous one, which shows the number of individuals in each category.

Female-breadwinner households and non-employed households generally represent the smallest proportions of total income (16.5\% and 10.5\%, respectively). Male-breadwinner households with children account for $10.0 \%$ of total income in the lowest quintiles and those without for $0.9 \%$, while dual-earner households with children account for $3.6 \%$ and those without for $0.3 \%$.

Much the largest income shares in each quintile are for dual-earner households and households with at least one female employed, in both cases without children, with figures of $78 \%$ and more for the former and $71 \%$ and more for the latter.

Comparing these figures with those of table 2 shows that female-breadwinner households (with and without children) received $12.8 \%$ of total family income and contained $12.4 \%$ of all individuals, while male-breadwinner households accounted for $32.1 \%$ of income and $36.9 \%$ of individuals. Thus, although total family income was lower in female-breadwinner households, male-breadwinner households had lower per capita income. Dividing the corresponding figures yields per capita incomes before taxes of US\$ 435 for male-breadwinner households with children and US\$1,035 for those without children. For female households, the corresponding figures were US\$ 463 and US\$1,118. 


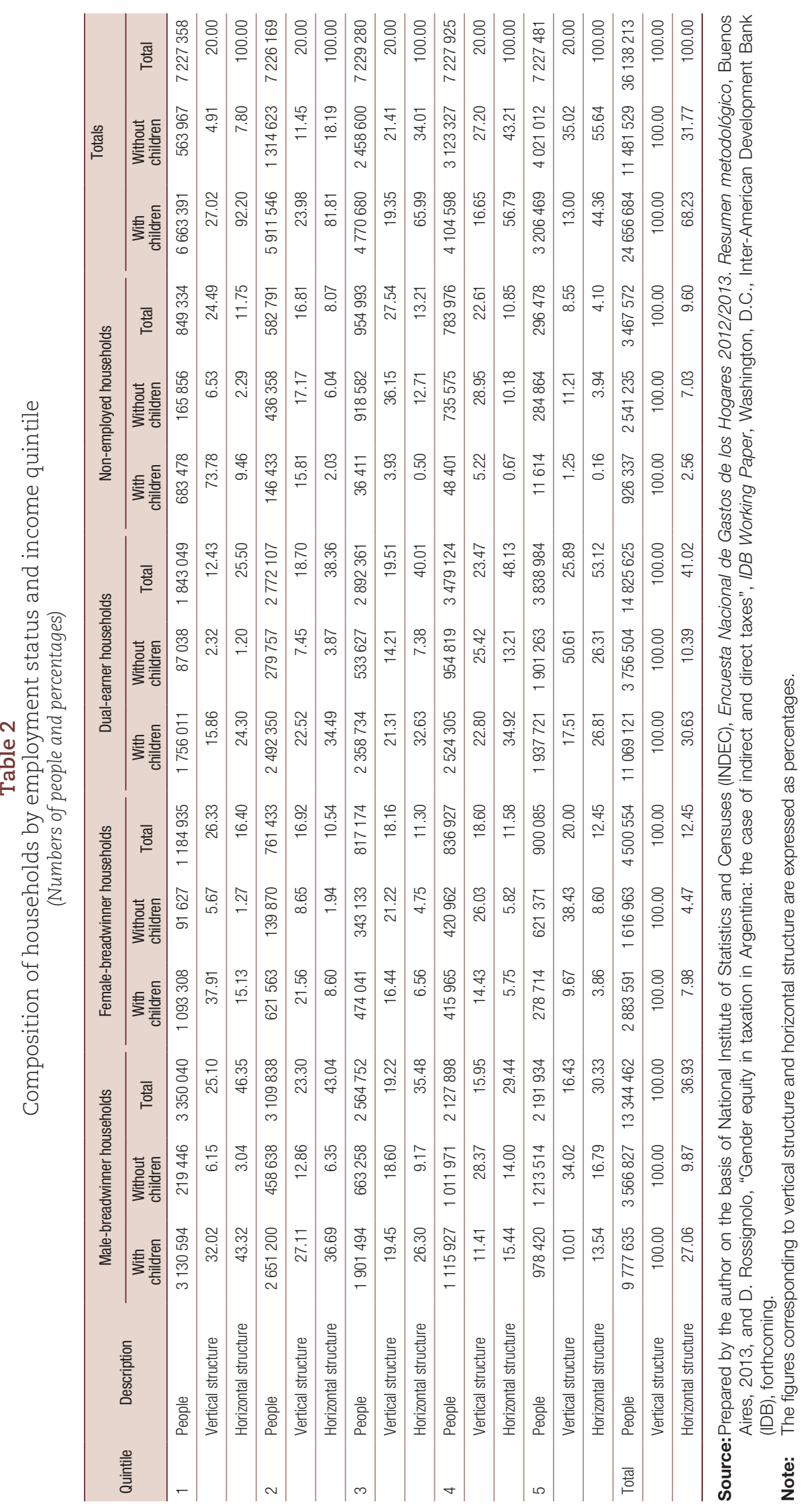




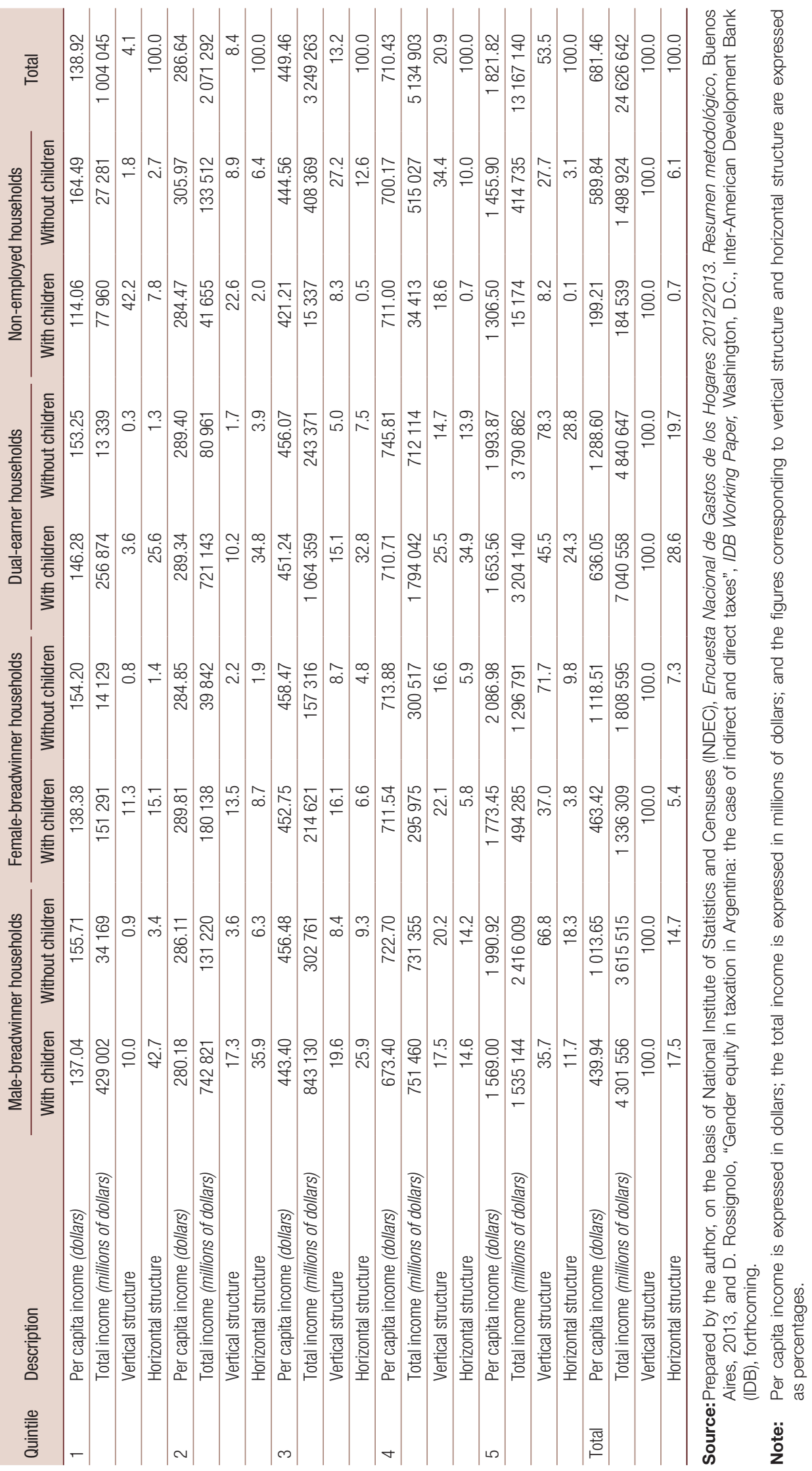




\section{Regulatory and methodological considerations concerning the taxes subjected to incidence analysis}

This section deals with the characteristics of the indirect and direct taxes analysed here, considering in each case the tax regulation structure, rate system and exemptions and the methodological procedure used. The indirect taxes considered were VAT, excise taxes, fuel taxes and provincial turnover taxes; the direct taxes analysed were personal income tax, payroll taxes and other minimum taxes on income (the monotributo). These taxes yielded about $71 \%$ of total tax revenues (national and provincial) in 2012, while the estimates provided here cover about $80 \%$ of the revenue from the universe of taxes taken into consideration (assuming no tax evasion).

\section{(a) Indirect taxes}

VAT is a consumption tax levied on the equivalent of value added at every stage of production. It is levied on imports in much the same way as on domestic production, but exports are zero-rated (via offsetting rebates). The $21 \%$ general rate is usually applied to taxable events, but there is also a $27 \%$ rate, mainly applicable to public services provided to companies subject to tax, and a $10.5 \%$ rate for a limited number of goods and services. VAT-related regulations include a list of exemptions. ${ }^{11}$ The trend in the design of this tax has been dictated by successive reforms aimed at broadening its base and increasing rates. VAT-exempt consumption amounted to $15 \%$ of total expenditure in 2006 (see Gómez Sabaini and Rossignolo, 2009).

The procedure for estimating the VAT contribution of each household in the ENGHo sample was to apply the relevant rates to each taxable or exempt item in the survey in accordance with the household's consumption pattern. Considering that the survey measures consumption expenditure, that no price data are included and that VAT is an ad valorem tax, if there are no other taxes affecting the tax base then the tax is calculated as:

$$
\text { taxpaid }_{i j}=\text { rate }_{j} *\left(\text { expend }_{i j} /\left(1+\sum_{j} \text { rate }_{j}\right)\right)
$$

where taxpaid $_{i j}$ is the tax paid by household $i$ on item $j$, rate ${ }_{j}$ is the tax rate on item $j$ and expend $d_{i j}$ is the reported expenditure for household $i$ on item $j$. Tax incidence for the $i^{\text {th }}$ household on the $k^{\text {th }}$ commodity group $\left(\bar{\theta}_{i}^{k}\right)$ is defined as the ratio between the per capita yearly tax (VAT) outlay of the $i^{\text {th }}$ household on the $k^{\text {th }}$ commodity group $\left(\bar{T}_{i}^{k}\right)$ and the per capita income of the $i^{\text {th }}$ household $\left(Y_{i_{i}}\right.$ ) (in the case of VAT). ${ }^{12}$

$$
\bar{\theta}_{i}^{k}=\bar{T}_{i}^{k} /\left(Y_{i_{i}}\right) \text {, where } \bar{T}_{i}=\sum_{k} \bar{T}_{i}^{k} \text { and } \bar{T}_{i}^{k}=\sum_{j} \bar{T}_{i j}, j \in k
$$

Excise tax is levied on the domestic sale and import of some specific goods: tobacco, alcoholic beverages, beer, carbonated and other non-alcoholic beverages, motor vehicles and diesel. In all cases where goods are taxed, the tax base includes the tax itself. As the actual tax may not be subtracted from the tax base, the effective tax rate is different from the nominal tax rate. Products made in Argentina and exported are exempt. DNIAF (2013) gives the rates for the main products.

\footnotetext{
11 The $10.5 \%$ rate includes fresh, refrigerated and frozen fruits, legumes and vegetables, grains, bread and domestic passenger transportation services, among other things. The main exemptions are for natural water, milk without additives and medicines.

12 The 1997 input/output table was used for exempt goods, taking data from 1993. For each exempt good the taxable proportion of inputs was estimated, the incidence of taxable inputs in the sales value of exempt goods was calculated and this structure was applied to the total for VAT purchases deriving from the consumption of exempt goods.
} 
For excise taxes on goods and services, each item was classified in accordance with tax regulations so that it could be matched to a similar item in the ENGHo, the usual assumption being made that these taxes are fully transferred to the price of the corresponding products.

In the case of fuel tax, liquid fuel and compressed natural gas were taxed as of 2012. DNIAF (2013) gives the products taxed, tax rates and minimum amounts per unit of measurement. Although there is no reliable study in Argentina determining the percentage of fuel costs going to form part of the transportation cost transferred to the consumer, it has been assumed that $30 \%$ of the tax is transferred at present, essentially because transport and fuel subsidies distort relative values.

The provincial turnover tax is a very important source of revenue for subnational governments and is applied by all provinces. It is levied at all stages of goods and services production and distribution, applies to gross income without deduction for tax already paid and accumulates through successive purchases. Each province's tax code lays down the basic principles of the tax, together with rates. In general, the highest rates are levied on commerce and services and financial intermediation (4.5\% to $5 \%)$, followed by industry and then the primary sector.

In order to calculate tax incidence, the tax rates were applied to reported consumption data. According to several authors (see, for instance, Rossignolo, 2015), effective tax rates are at least twice as high as rates for final consumption, and rates on retail consumption have accordingly been increased by $150 \%$ to reflect this. This tax is the closest to input costs and should be included in calculations of the tax base for VAT and excise taxes.

\section{(b) Direct taxes}

It is commonly assumed that for personal income tax and other taxes related to income, the economic incidence is the same as the statutory incidence. For payroll taxes, it is assumed that the burden is completely borne by employees through a reduced wage. Household surveys report net income for wage workers, i.e. earnings after social security contributions.

Surveys rarely report how much respondents paid in income taxes. For formal workers, after-tax income is reported, which means that reported earnings ought to be grossed up to arrive at pre-tax income. For non-formal wage workers, employers, self-employed workers, recipients of capital income, social security beneficiaries, pensioners and beneficiaries of public transfers, reported income reflects earnings before taxes. Arriving at the tax burden means calculating tax revenues from all these sources, assuming they represent taxable income (except for transfers).

Personal income tax applies to manifold types of income and is structured with progressive rates; its tax base has been expanded by numerous resolutions. The Income Tax $\mathrm{Act}^{13}$ sets forth four categories of income by source, namely land rent, capital gains, corporate and certain business brokers' income, and personal income. A single taxpayer may generate income in more than one income category at the same time. Taxable income is calculated from income and expenses in the four categories and from holdings in companies or activities. Net taxable income is calculated by deducting costs, ${ }^{14}$ allowable personal expenses, dependency allowances, the minimum non-taxable income threshold and the special deduction from income. The monthly earnings of wage workers are subject to withholdings made by employers, who are responsible for paying the tax owing to the tax authorities.

\footnotetext{
13 Income tax is governed by Law No. 20628, which was enacted in 1973 and subsequently amended and regulated on numerous occasions.

${ }^{14}$ Authorized expenses are those "incurred to obtain, maintain and preserve the income subject to the tax" and are subtracted from the income produced by the source giving rise to them.
} 
There are exemptions for interest on saving account deposits and term deposits, income from securities, shares, bonds, bills of exchange, notes and other paper issued or to be issued in the future by a government authority and the rental value of owner-occupied residences, among other things. Pensions, retirement payments, subsidies and pay received during medical leave are not exempt.

For formal workers, tax rates depend on the taxable net income bracket their earnings fall into. The system is based on a sliding scale consisting of a fixed amount plus the amount calculated by applying a rate ranging from $9 \%$ to $35 \%$ on the excess over the base level of each income bracket (see DNIAF, 2013). Pre-tax income is reported for all other earners, so that thresholds and deductions should be applied in accordance with the tax bracket this income falls into in order to calculate the amount of tax collected.

There is a group of "small taxpayers" whose gross income does not exceed US\$ 65,800 annually and who are taxed under the simplified monotributo regime, paying a fixed amount of tax each month in a single payment that replaces personal income tax and VAT plus social security and health insurance contributions. The income tax included in the single payment is based on income bracket, with earnings being estimated from turnover, the surface area of production facilities, the use of power during production or a combination of these (see DNIAF, 2013), and no rules for assessing income, standard deductions, dependents or special deductions are applied. A fixed amount of tax is levied in accordance with the monotributo category into which taxpayers fall.

Incidence was calculated by taking the individual earnings of self-employed people and employers and checking whether their reported (pre-tax) income was below the threshold established by the tax code. All the taxpayers selected were to be excluded from the personal income tax base.

Payroll taxes and social security contributions were also included for formal and non-formal workers. They were calculated in two parts: revenue generated by formal workers and the amount paid by self-employed workers. The household survey provides information on the former by reporting whether the employer has withheld employee contributions at source, thus paying both the employer's and the employee's dues. In the case of the self-employed, since no evasion is assumed, the calculations assume that they are contributing to the social security system as long as they have not been included in the monotributo regime.

In the case of the formal sector, incidence was estimated using statutory rates (see DNIAF, 2013) by "grossing up" wage workers' income as reported in the survey, net of personal income tax. In the case of the self-employed (whose earnings are reported pre-tax), the calculation used progressive tax rates differing between professionals and traders, who were identified in the household survey by years of education.

\section{Estimation results}

This section presents the incidence analysis results. The variable used in the analysis is tax as a percentage of pre-tax per capita income; all tables show mean values. The results will be presented separately for indirect and direct taxes and the different pre-tax per capita income quintiles. ${ }^{15}$

Table 4 shows the overall incidence of the tax system. Taxes are progressive overall, since the progressivity of direct taxes more than compensates for the regressivity of indirect ones; the average aggregate tax burden is $33.4 \%$.

15 Standard errors are available from the author upon request. 
Table 4

Taxes as a share of pre-tax income, by tax and per capita income quintile (Percentages)

\begin{tabular}{rrrrrrrrrrrr}
\hline Quintile & $\begin{array}{c}\text { Total indirect } \\
\text { taxes }\end{array}$ & $\begin{array}{c}\text { Value } \\
\text { added tax }\end{array}$ & $\begin{array}{c}\text { Turnover } \\
\text { tax }\end{array}$ & Excise tax & Fuel tax & $\begin{array}{c}\text { Total direct } \\
\text { taxes }\end{array}$ & $\begin{array}{c}\text { Personal } \\
\text { income tax }\end{array}$ & $\begin{array}{c}\text { Payroll } \\
\text { taxes }\end{array}$ & $\begin{array}{c}\text { Minimum/ } \\
\text { other direct } \\
\text { taxes }\end{array}$ & $\begin{array}{c}\text { Total tax } \\
\text { system }\end{array}$ \\
\hline 1 & 22.43 & 13.41 & 6.85 & 1.47 & 0.69 & 5.97 & 0.00 & 5.25 & 0.72 & 28.40 \\
\hline 2 & 0.44 & 0.24 & 0.15 & 0.09 & 0.05 & 0.42 & 0.00 & 0.43 & 0.04 & 0.58 \\
\hline & 16.93 & 9.98 & 5.22 & 0.97 & 0.76 & 13.52 & 0.00 & 12.93 & 0.59 & 30.46 \\
\hline 3 & 0.48 & 0.28 & 0.15 & 0.04 & 0.06 & 0.49 & 0.00 & 0.51 & 0.03 & 0.65 \\
\hline & 13.70 & 8.09 & 4.32 & 0.70 & 0.75 & 16.74 & 0.00 & 16.21 & 0.53 & 30.61 \\
\hline 4 & 0.28 & 0.16 & 0.09 & 0.03 & 0.05 & 0.50 & 0.00 & 0.51 & 0.04 & 0.51 \\
\hline & 12.33 & 7.17 & 3.84 & 0.56 & 0.77 & 20.54 & 0.37 & 19.63 & 0.54 & 32.87 \\
\hline 5 & 0.21 & 0.12 & 0.07 & 0.02 & 0.04 & 0.44 & 0.09 & 0.44 & 0.04 & 0.43 \\
\hline & 8.64 & 4.95 & 2.68 & 0.32 & 0.68 & 36.02 & 10.06 & 25.43 & 0.53 & 44.66 \\
\hline Total & 0.17 & 0.10 & 0.06 & 0.01 & 0.03 & 0.55 & 0.30 & 0.36 & 0.05 & 0.53 \\
\hline & 14.84 & 8.72 & 4.58 & 0.80 & 0.73 & 18.56 & 2.09 & 15.89 & 0.58 & 33.40 \\
\hline
\end{tabular}

Source:Prepared by the author on the basis of National Institute of Statistics and Censuses (INDEC), Encuesta Nacional de Gastos de los Hogares 2012/2013. Resumen metodológico, Buenos Aires, 2013, and D. Rossignolo, "Gender equity in taxation in Argentina: the case of indirect and direct taxes", IDB Working Paper, Washington, D.C., Inter-American Development Bank (IDB), forthcoming.

It can be observed that the indirect tax burden for all households averages $14.8 \%$ of income. Most of that results from the large impact of VAT, whose average incidence overall is $8.7 \%$, while the aggregate tax burden of the turnover tax is $4.5 \%$. The incidence of excise and fuel taxes is similar at around $1.2 \%$ of per capita income. The largest burden is borne by female-breadwinner households (16.2\%).

Indirect taxes are very regressive in the aggregate: the burden is $22.4 \%$ in the first quintile, decreasing to $8.6 \%$ in the highest quintile. To take the taxes separately, VAT is regressive, with the first quintile having a burden of $13.4 \%$ and the fifth one of $4.9 \%$, and so are excise taxes, with burdens of $1.5 \%$ and $0.3 \%$, respectively. The differences are statistically significant in all cases. The fuel tax is more or less proportional, with both the first and fifth quintiles having burdens of $0.6 \%$.

Table 5 and figure 4 present the estimated aggregate incidence of direct, indirect and total taxes by household type, while table A1.1 of the annex presents the results disaggregated by type of tax. None-employed households without children in the first quintile bear the largest indirect tax burden (31.8\%), while female breadwinners with children show the most regressive burden. Dual-earner households without children have the smallest average burden over all quintiles.

VAT incidence by household type and quintile is what most heavily influences overall tax behaviour, and it is particularly strong in the lower segments of the distribution. Although non-employed households without children in the poorest quintile face the largest VAT burden, female-breadwinner households in that quintile still bear a larger burden than male-breadwinner or dual-earner households.

Male-breadwinner households without children exhibit the greatest regressivity in the first quintile, only to be displaced in the second quintile by dual earners in the case of excise taxes. In the fourth and fifth quintiles, male-breadwinner households once again have the largest tax burden. 
Table 5

Taxes as a share of pre-tax income, by household type and per capita income quintile (Percentages)

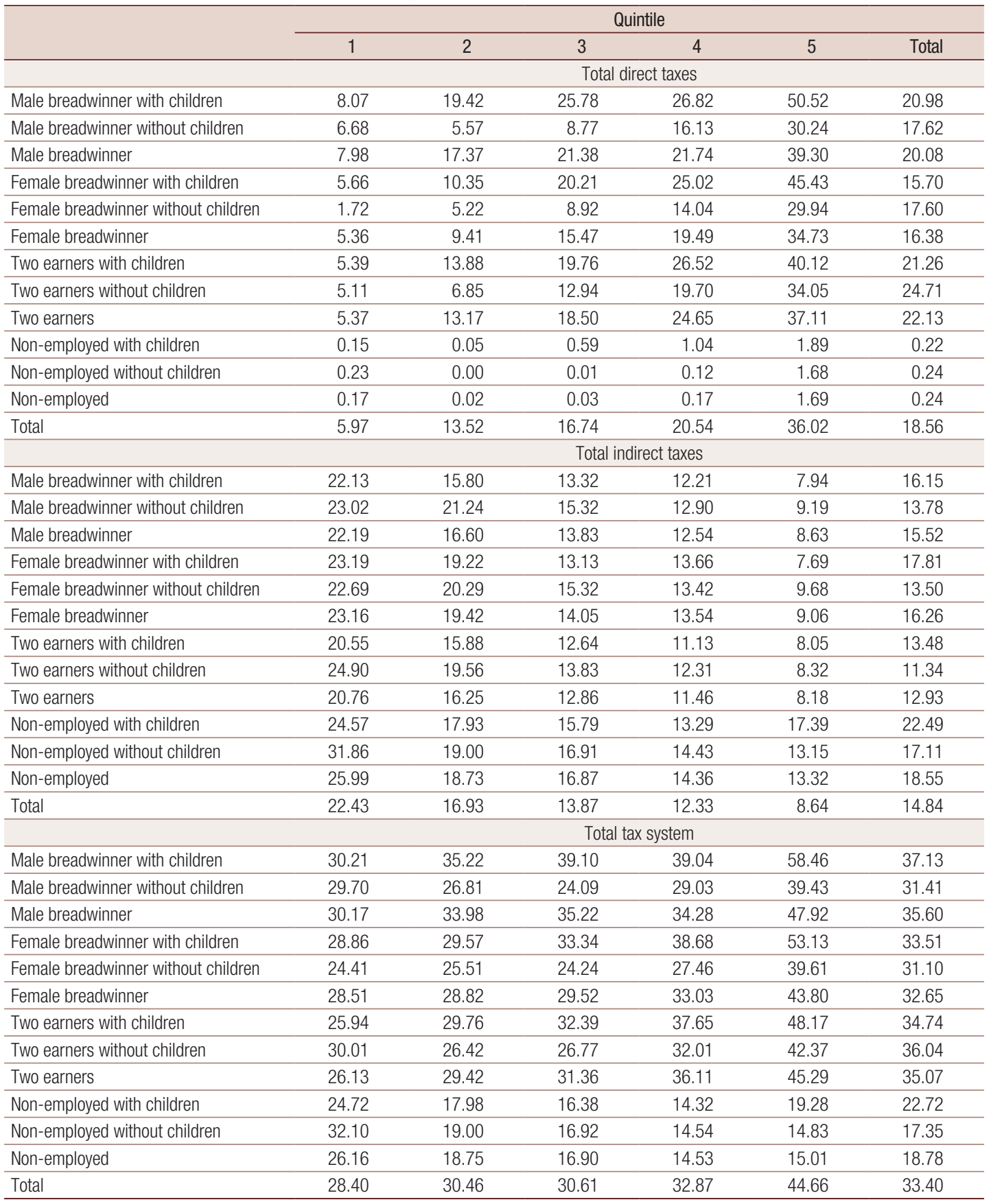

Source:Prepared by the author on the basis of National Institute of Statistics and Censuses (INDEC), Encuesta Nacional de Gastos de los Hogares 2012/2013. Resumen metodológico, Buenos Aires, 2013, and D. Rossignolo, "Gender equity in taxation in Argentina: the case of indirect and direct taxes", IDB Working Paper, Washington, D.C., Inter-American Development Bank (IDB), forthcoming. 
Figure 4

Indirect taxes as a share of pre-tax income, by household type and per capita income quintile (Percentages)
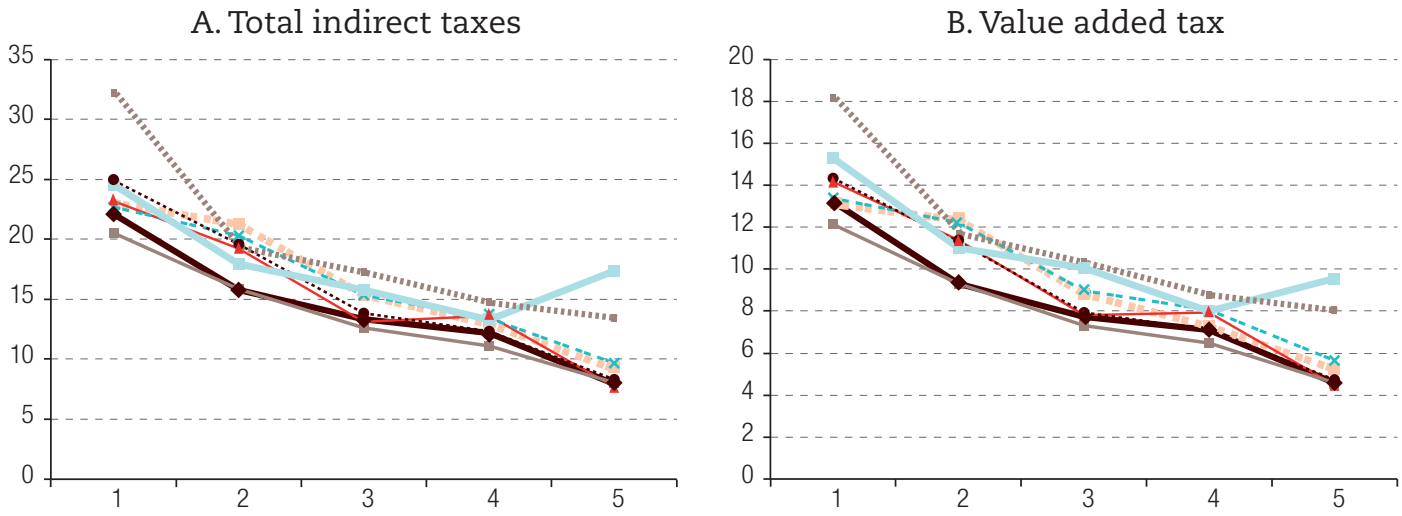

C. Excise tax

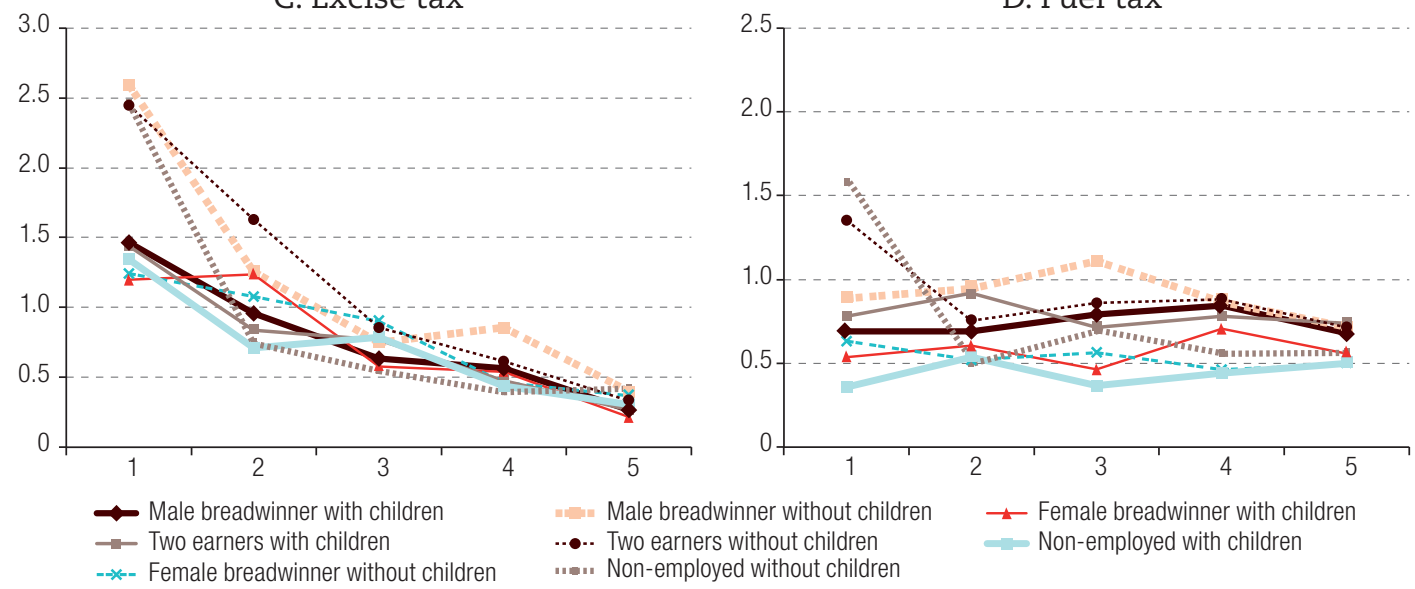

Source:Prepared by the author on the basis of National Institute of Statistics and Censuses (INDEC), Encuesta Nacional de Gastos de los Hogares 2012/2013. Resumen metodológico, Buenos Aires, 2013, and D. Rossignolo, "Gender equity in taxation in Argentina: the case of indirect and direct taxes", IDB Working Paper, Washington, D.C., Inter-American Development Bank (IDB), forthcoming.

Fuel taxes are fairly proportional, with the highest burden in the first quintile being for dual-earner and non-employed households, while in the case of turnover tax the pattern is regressive except for non-employed households with children, which display a $U$ shape. These households have the largest fuel tax burden.

In the case of direct taxes, the estimations included personal income tax, payroll taxes and minimum or presumptive taxes on income. The burden of personal income tax is low by the standards of countries in the Organization for Economic Cooperation and Development (OECD) (Gómez Sabaini, Jiménez and Rossignolo, 2012), which reduces the redistributive effect that can be expected of it. It is heavily concentrated in the highest income quintiles, with the lowest brackets being outside the personal income tax net. These lower-income individuals, and many of those included in higher-income quintiles but working on their own account, are meant to pay the minimum or presumptive tax (monotributo), whose impact on the distribution of the tax burden is a matter of debate.

In table 4, it can be observed that the burden for all households and taxes is $18.5 \%$. Most of that results from the large impact of payroll taxes, whose total average incidence is $15.8 \%$. On aggregate, direct taxes are markedly progressive, with a burden of $5.9 \%$ in the lowest-income quintile, rising 
to $36.0 \%$ in the highest quintile. However, the analysis by tax shows that while personal income tax and payroll taxes are progressive, the monotributo is moderately regressive, as the first quintile bears a burden of $0.7 \%$ and the fifth one of $0.5 \%$. All differences in tax burdens across quintiles and within household classifications are statistically significant (tables 5 and A1.1 of the annex). ${ }^{16}$

Figure 5 shows aggregate results for the estimated incidence of the direct taxes under consideration, by household type. The largest burden is borne by dual-earner households (22.1\%). All taxes except the monotributo follow a similar pattern, and almost all household types exhibit a similar progressivity up the first four quintiles, with a peak in the fifth due to the personal income tax. The largest burden is borne by male-breadwinner households in all income quintiles, and the tax burden is invariably heavier for households with children.

Figure 5

Direct and total taxes as a share of pre-tax income, by household type and per capita income quintile

(Percentages)

A. Total direct taxes

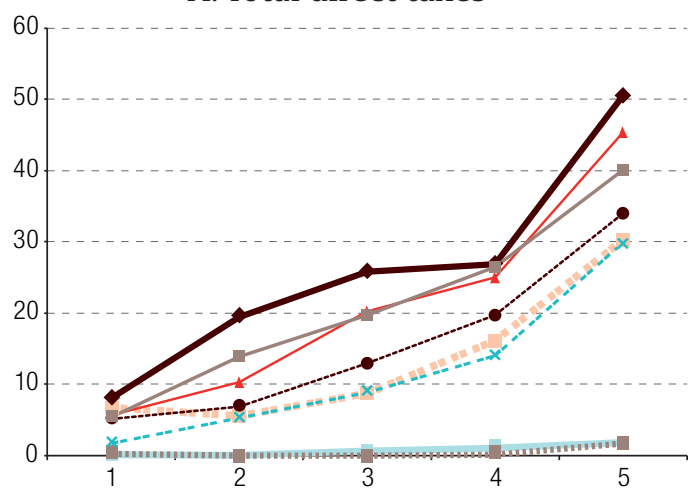

C. Payroll taxes

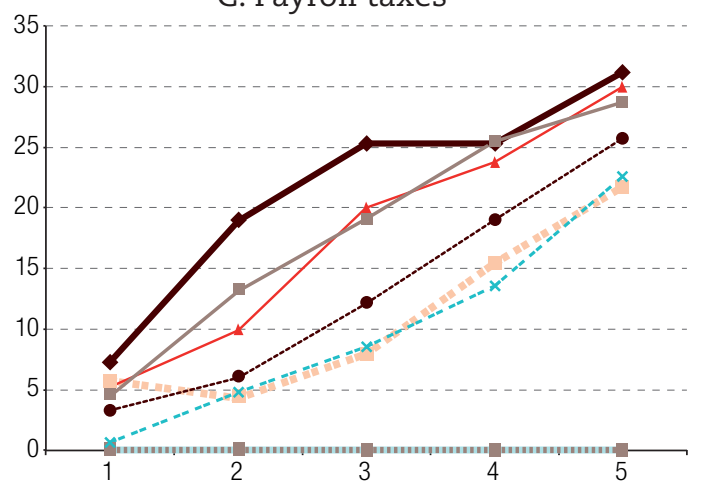

- Male breadwinner with children

$\rightarrow$ - Two earners with children

$--x$ - Female breadwinner without children
B. Personal income tax

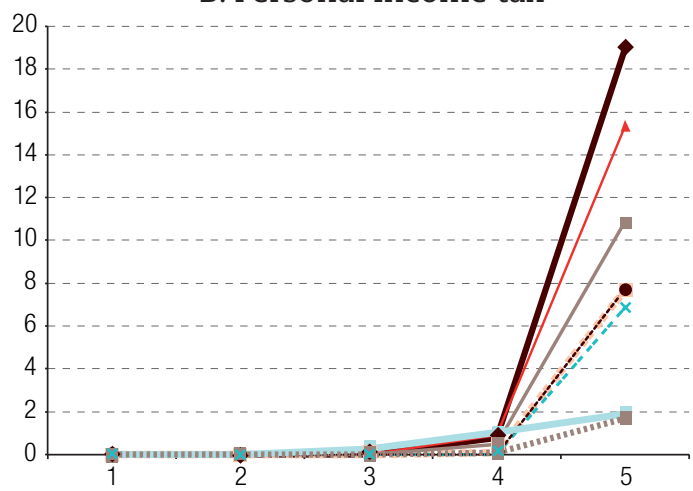

D. Total taxes

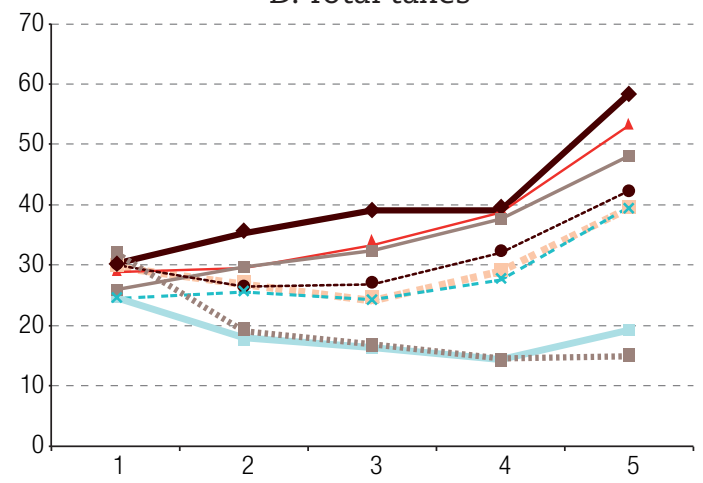

Male breadwinner without children $\quad \longrightarrow$ Female breadwinner with children
- - Two earners without children

"I" Non-employed without children

Source: Prepared by the author on the basis of National Institute of Statistics and Censuses (INDEC), Encuesta Nacional de Gastos de los Hogares 2012/2013. Resumen metodológico, Buenos Aires, 2013, and D. Rossignolo, "Gender equity in taxation in Argentina: the case of indirect and direct taxes", IDB Working Paper, Washington, D.C., Inter-American Development Bank (IDB), forthcoming.

\footnotetext{
${ }^{16}$ All tests for significance across the different household classifications and the different quintiles within each household classification are available from the author upon request.
} 
Almost all personal income tax is paid by households in the fourth and fifth quintiles. Households with children bear the largest burden of this tax, as they account for a higher proportion of total income than those without children, and male breadwinners have the heaviest burden in the fifth quintile.

High thresholds and deductions mean that personal income tax is paid by few people, and this makes it progressive, with most of the burden falling on the highest quintile. Male-breadwinner and female-breadwinner households have the largest burden, while households where no-one is employed, being outside the formal sector, have the smallest.

The incidence of payroll taxes as a share of pre-tax income is also progressive, it once again being male-breadwinner households with children that bear the largest burden. The monotributo, on the contrary, is moderately regressive. The largest burden is borne by male-breadwinner households without children, but this tax is most regressive for dual-earner households without children.

The largest average burden of personal income tax is borne by male-breadwinner households without children (2.6\%), while in the fifth quintile male-breadwinner households with children pay the most. The largest monotributo burden falls on male-breadwinner households with children, particularly in the richest quintile. Female-breadwinner households bear a larger burden than male-breadwinner households in the first quintile, as they are more likely to be own-account workers who do not pay personal income tax.

On aggregate, and as far as the taxes analysed are concerned, the tax system is progressive. The tax burden falls most heavily on male-breadwinner, female-breadwinner and dual-earner households and is higher for all types of households with children except those where no-one is employed. The burden for households without children tends to be quite proportional, whereas the burden for households where no-one is employed is more regressive. As mentioned earlier, these results stem from the fact that male-breadwinner households have lower per capita income than female-breadwinner ones.

\section{Summary and conclusions}

The main aim of this research was to analyse how the tax system affected gender equity in Argentina, and specifically whether it promoted it. Argentina's tax system has undergone significant and very frequent changes over the past two decades. However, these have not been part of a comprehensive reform but have been designed as stopgap resource-raising measures to cover budget deficits, and very few have been intended to improve equity.

The analysis of indirect taxes included VAT, excise taxes, fuel tax and provincial turnover taxes, while the direct taxes included were personal income tax, payroll taxes and minimum or presumptive taxes. The welfare indicator employed was pre-tax per capita income, and the analysis was carried out for per capita income quintiles and household categories based on employment status, with individuals being ranked in the same way.

When the burden of indirect taxes on income is analysed, striking differences emerge. For instance, female-breadwinner households bear the largest burden, since they are concentrated in a lower part of the income distribution than other household types, such as the male-breadwinner and dual-earner types. The indirect tax system is heavily regressive overall and in the specific cases of VAT, excise taxes and the turnover tax; while fuel taxes, unlike these, are fairly proportional, they are not enough to not offset this effect. Households without children have a larger share of the tax burden, particularly female-breadwinner ones. 
Personal income taxation in Argentina has strengths and weaknesses when it comes to gender equity. The individual taxation principle is one of the system's strengths because it does not a priori discourage women from earning; nevertheless, there is formal discrimination against women insofar as they have no tax liability for joint income.

An important aspect of Argentina's personal income tax system is its segmentation into three different categories of taxpayers (wage workers, high-income self-employed and low-income self-employed paying the monotributo) subject to different thresholds and deductions. Another type of discrimination arises from the personal income tax code in Argentina, which simultaneously entails horizontal and vertical inequity, in the form of provisions for exemptions. People obtaining their income from their own work have to pay income tax, assuming they earn above the threshold. Conversely, people obtaining their income from capital (e.g. by participating in the stock market) do not have to pay income tax. People with high incomes, especially men, are overrepresented among the latter.

Households with children have the highest direct tax burden, particularly male-breadwinner and dual-earner households. The low impact of personal income tax, which is only paid by the top $30 \%$ or so of earners, reduces the scope for using this tax to pursue equity-oriented policies.

A number of policy measures for reducing the burden of indirect taxes on the poorest femalebreadwinner households can be suggested. Cutting the VAT rate on a basket of selected foods, public transportation and children's clothing while increasing excise taxes on luxury goods would make indirect taxes more equitable. In the case of direct taxes, broadening the personal income tax base to cover capital income, most of which is received by male-breadwinner households, would also improve gender equity.

\section{Bibliography}

Bourguignon, F. and L. Pereira da Silva (2003), "Evaluating the poverty and distributional impact of economic policies: a compendium of existing techniques", The Impact of Economic Policies on Poverty and Income Distribution: Evaluation Techniques and Tools, F. Bourguignon and L. Pereira da Silva (eds.), Washington, D.C., World Bank.

DNIAF (National Office for Fiscal Investigation and Analysis) (2013), "Tributos vigentes en la República Argentina 2012", Buenos Aires.

Doss, C. (2011), "Intrahousehold bargaining and resource allocation in developing countries" [online] http://siteresources.worldbank.org/INTWDR2012/Resources/7778105-1299699968583/77862101322671773271/Doss-Intrahh-bargaining.pdf.

Gasparini, L. (1998), "Incidencia distributiva del sistema impositivo argentino", La reforma tributaria en la Argentina, Buenos Aires, Foundation of Latin American Economic Research.

Gómez Sabaini, J. C., M. Harriague and D. Rossignolo (2013), "La situación fiscal en Argentina y sus efectos sobre la distribución del ingreso”, Desarrollo Económico, vol. 52, No. 207-208, Buenos Aires, Institute of Economic and Social Development.

Gómez Sabaini, J. C., J. P. Jiménez and D. Rossignolo (2012), "Imposición a la renta personal y equidad en América Latina: nuevos desafíos", Macroeconomics of Development series, No. 119 (LC/L.3477-P), Santiago, Economic Commission for Latin America and the Caribbean (ECLAC).

Gómez Sabaini, J. C. and D. Rossignolo (2009), "Argentina: análisis de la situación tributaria y propuestas de reformas impositivas destinadas a mejorar la distribución del ingreso", Reflexiones y propuestas para mejorar la distribución del ingreso en Argentina, S. Keifman, Buenos Aires, International Labour Organization (ILO).

Gómez Sabaini, J. C., J. J. Santiere and D. Rossignolo (2002), "La equidad distributiva y el sistema tributario: un análisis para el caso argentino", Public Administration series, No. 20 (LC/L.1733-P), Santiago, Economic Commission for Latin America and the Caribbean (ECLAC). 
Grown, C. (2010), "Taxation and gender equality", Taxation and Gender Equity: A Comparative Analysis of Direct and Indirect Taxes in Developing and Developed Countries, C. Grown and I. Valodia (eds.), New York, Routledge.

Grown, C. and I. Valodia (eds.) (2010), Taxation and Gender Equity: A Comparative Analysis of Direct and Indirect Taxes in Developing and Developed Countries, C. Grown and I. Valodia (eds.), New York, Routledge.

INDEC (National Institute of Statistics and Censuses) (2013), Encuesta Nacional de Gastos de los Hogares 2012/2013. Resumen metodológico, Buenos Aires.

Lambert, P. (1993), The Distribution and Redistribution of Income: A Mathematical Analysis, Manchester, Manchester University Press.

Rodríguez Enríquez, C., N. Gherardi and D. Rossignolo (2010), "Gender equality and taxation: the Argentine case", Taxation and Gender Equity: A Comparative Analysis of Direct and Indirect Taxes in Developing and Developed Countries, C. Grown and I. Valodia (eds.), New York, Routledge.

Rossignolo, D. (2016), "Gender equity in taxation in Argentina: the case of indirect and direct taxes", IDB Working Paper, Washington, D.C., Inter-American Development Bank (IDB), forthcoming.

(2015), "Externalidades tributarias verticales: una estimación empírica en impuestos sobre los consumos en Argentina", Urban Public Economics Review, No. 21, Santiago de Compostela, University of Santiago de Compostela.

Sahn, D. and S. Younger (2003), "Estimating the incidence of indirect taxes in developing countries", The Impact of Economic Policies on Poverty and Income Distribution: Evaluation Techniques and Tools, F. Bourguignon and L. Pereira da Silva (eds.), Washington, D.C., World Bank.

Stotsky, J. (1996), "Gender bias in tax systems”, IMF Working Paper, No. 96/99, Washington, D.C., International Monetary Fund (IMF). 


\section{Annex A1}

Table A1.1

Taxes as a share of pre-tax income, by household type and per capita income quintile (Percentages)

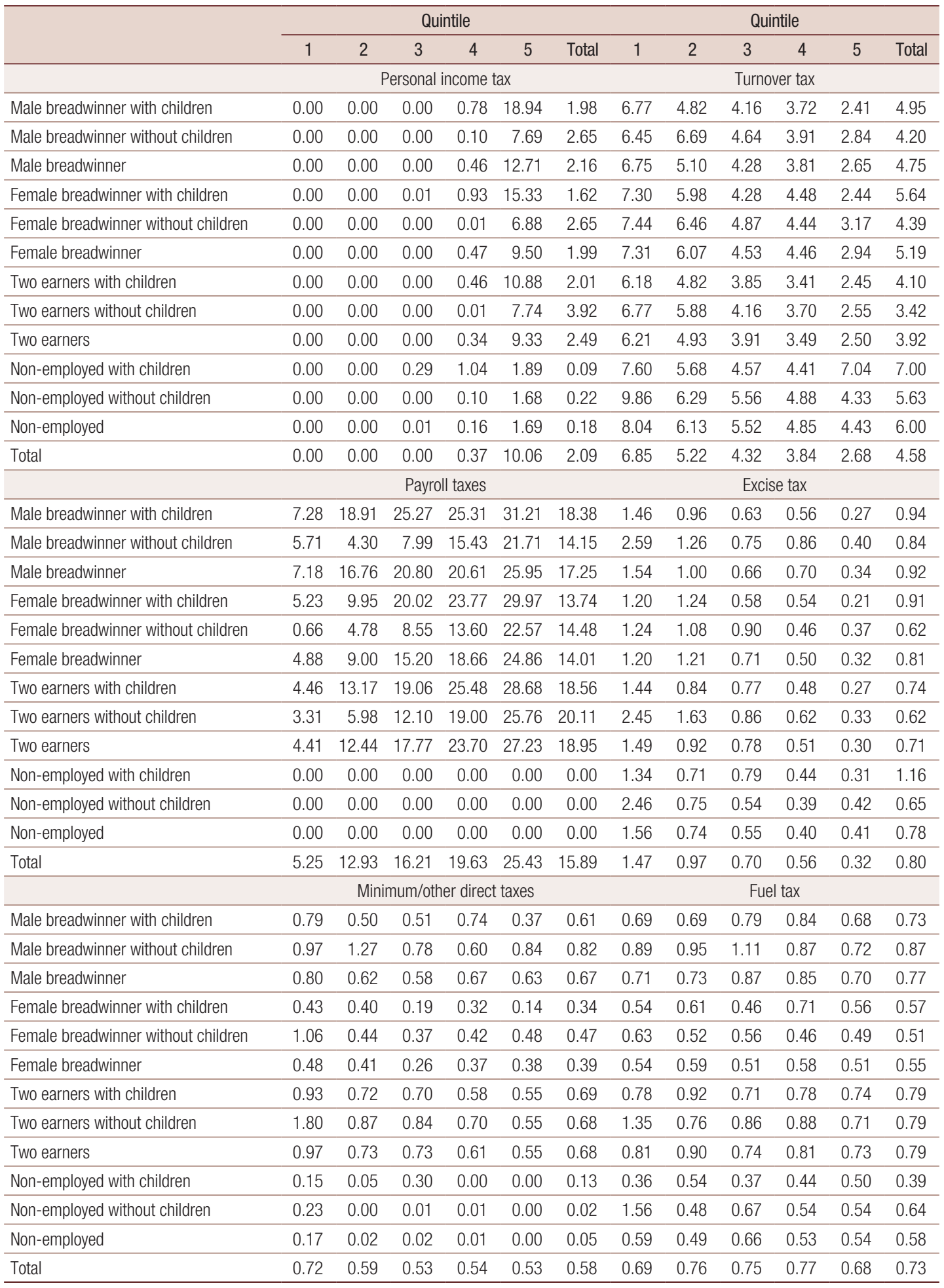


Table A1.1 (concluded)

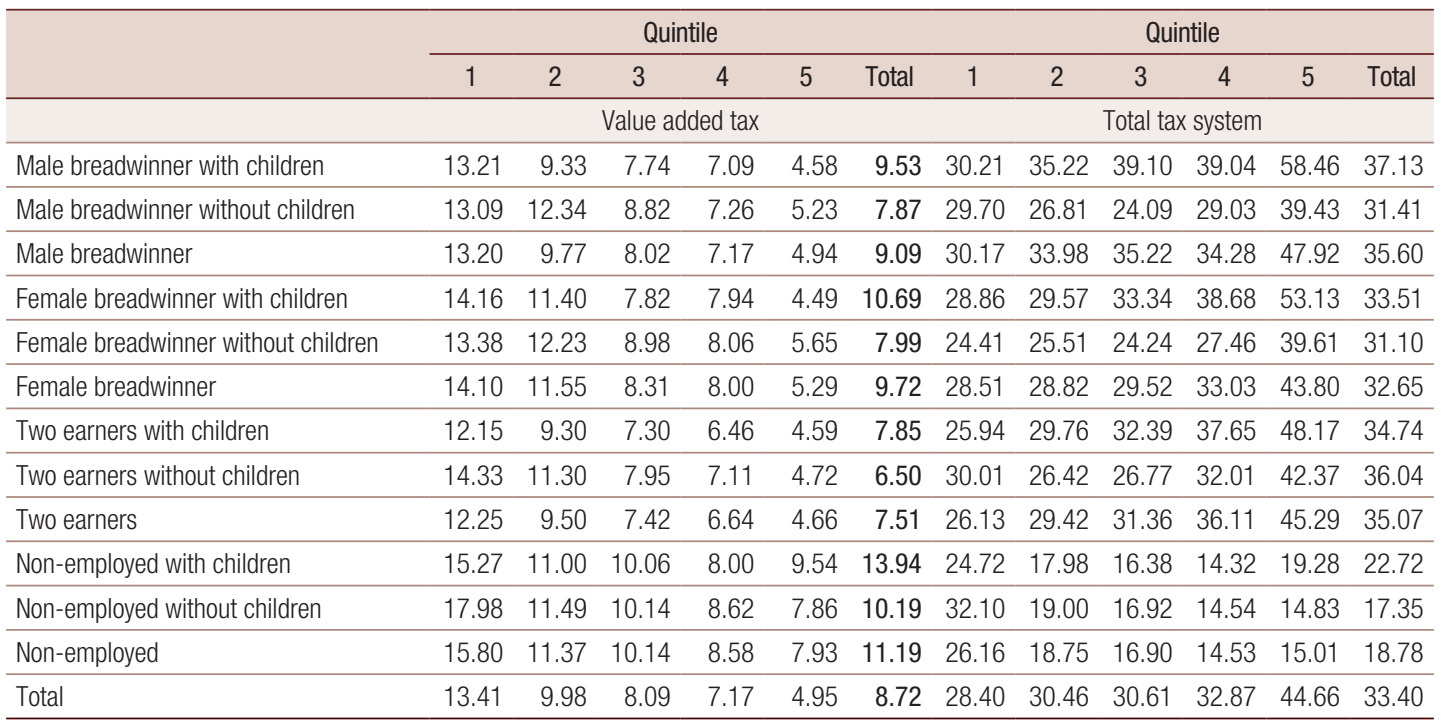

Source:Prepared by the author on the basis of National Institute of Statistics and Censuses (INDEC), Encuesta Nacional de Gastos de los Hogares 2012/2013. Resumen metodológico, Buenos Aires, 2013, and D. Rossignolo, "Gender equity in taxation in Argentina: the case of indirect and direct taxes", IDB Working Paper, Washington, D.C., Inter-American Development Bank (IDB), forthcoming. 